\title{
PATIENT'S CHEST DISCOMFORT ASSOCIATED WITH DELAY IN REPERFUSION THERAPY ACUTE CORONARY SYNDROME
}

\author{
Elizabeth Yun Yun Vinsur', Djanggan Sargowo', Tony Suharsono ${ }^{3}$ \\ ${ }^{1}$ Program Studi Magister Keperawatan, Fakultas Kedokteran, Universitas Brawijaya Malang \\ 2IImu penyakit Jantung dan Pembuluh Darah, Fakultas Kedokteran, Universitas Brawijaya Malang \\ ${ }^{3} J u r u s a n$ IImu Keperawatan, Fakultas Kedokteran, Universitas Brawijaya Malang
}

\begin{abstract}
Acute Coronary Syndrome (ACS) is a group of symptoms that are classify as unstable angina (ATS), STSegment Elevation Myocardial Infarction (STEMI) and non ST-Segment Elevation Myocardial Infarction (NSTEMI). Main objective to provide timely reperfusion therapy is essential to improve survival. Initial and rapid intervention after the occurrence of coronary artery disease is associated with better clinical outcomes, but it is hampered by the nature of the patient's seeking decisionsPatients expect the type of heart attack they often see in medical movies and television: like chest pain that grips and causes it to fall to the floor. This study aims to analyze the chest discomfort experienced by patients associated with delay in reperfusion therapy of Acute Coronary Syndrome. The method used is observational analytic with cross sectional approach. Nonprobability sampling with time quota technique obtained sample of 60 respondents. The results obtained as many as 55\% of patients come more than 120 minutes after the onset of discomfort in the chest. The patient's delay in coming to the associated hospital is an accompanying symptom factor at onset with $p=0.048$, and $O R=4.596$ (1.014-20.828). There were no significant differences in the scores of knowledge, behavior, and beliefs based on the ACS response index between patients who came $<120$ minutes and $>120$ minutes. The conclusions of this study present the accompanying symptom presentations at onset with the time interval between the appearances of the SKA symptoms until arriving at the IGD door. Seeing the results of this study suggests the need for efforts from medical staff to optimize the interpretation of "chest pain characteristics" to patients and families or who are susceptible about specific and non-specific cardiac signs.
\end{abstract}

Keywords: acute coronary syndrome, prehospital delay, onset to door, reperfusion

\section{ABSTRAK}

Sindrom Koroner Akut (SKA) merupakan sekelompok gejala yang diklasifikasikan sebagai angina tidak stabil (ATS), ST-Segment Elevation Myocardial Infarction (STEMI) dan non ST-Segment Elevation Myocardial Infarction (NSTEMI). Pemberian terapi reperfusi tepat waktu sangat penting untuk meningkatkan kelangsungan hidup. Intervensi awal dan cepat setelah terjadinya penyakit arteri koroner berkaitan dengan hasil klinis yang lebih baik, tetapi hal tersebut terhambat oleh sifat alami keputusan mencari bantuan dari pasien. Pasien mengharapkan jenis serangan jantung yang sering mereka lihat di film dan televisi medis: seperti nyeri dada yang mencengkeram dan menyebabkan jatuh ke lantai. Penelitian ini bertujuan untuk menganalisa ketidaknyamanan dada yang dialami penderita yang berhubungan dengan keterlambatan waktu terapi reperfusi Sindrom Koroner Akut. Metode yang digunakan adalah observasional analitik dengan pendekatan cross sectional. Nonprobability sampling dengan teknik kuota waktu didapatkan sampel sebanyak 60 responden. Hasil penelitian didapatkan sebanyak 55\% pasien datang lebih dari 120 menit setelah onsetketidaknyamanan di dada. Keterlambatan pasien datang ke rumah sakit yang berhubungan adalah faktor gejala penyerta saat onset dengan $p=0.048$, dan $O R=4.596$ (1.014-20.828). Tidak terdapat perbedaan yang signifikan dalam hal skor pengetahuan, perilaku, dan keyakinan berdasarkan ACS response index antara pasien yang datang $<120$ menit dan $>120$ menit. Kesimpulan dari penelitian ini presentasi gejala yang menyertai saat onset berhubungan dengan interval waktu antara munculnya gejala SKA sampai tiba di pintu IGD. Melihat hasil penelitian ini mengisyaratkan tentang perlunya upaya dari petugas medis untuk mengoptimalkan penafsiran tentang "ciri khas nyeri dada" ke pasien dan keluarga atau yang rentan tentang tanda gejala spesifik dan tidak spesifik jantung.

Kata Kunci: sindrom koroner akut, keterlambatan pra rumah sakit, serangan ke pintu IGD, reperfusi.

Jurnal Imu Keperawatan, Vol. 6, No. 1, Mei 2018. Korespondensi: Elizabeth Yun Yun Vinsur. Magister Keperawatan FKUB. Jl. Pulosari 3/19a Blimbing-Malang, Kode Pos: 65125. Email: lizavinsur.LV@gmail.com. No. Hp +628 563577434 atau No. telp. (0341) 476173. 


\section{PENDAHULUAN}

Penyakit kardiovaskular menjadi alasan utama kematian lebih dari 16 juta orang per tahun. Lebih dari $\mathbf{8 0 \%}$ kematian ini terjadi di negara-negara berkembang (Vahedian Azimi et al., 2010). Prevalensi total penyakit jantung koroner (PJK) di negara maju misalnya AS adalah 6,2\% untuk usia di atas 20 tahun (Mozaffarian et al., 2015). Prevalensi PJK di negara berkembang di Indonesia, PJK menduduki peringkat ketiga dari seluruh penyebab kematian di Indonesia. Prevalensi PJK pada umur $\geq 15$ tahun berdasarkan diagnosa dan menurut diagnosis atau gejala oleh dokter masing-masing 0,5\% dan 1,5\% (Kesehatan and RI, 2013).

Sindrom Koroner Akut (SKA) merupakan sekelompok gejala yang diklasifikasikan sebagai angina tidak stabil (ATS), ST- Segment Elevation Myocardial Infarction (STEMI) dan non ST-Segment Elevation Myocardial Infarction (NSTEMI) (Darawad et al., 2015). Data statistik dari American Heart Association (AHA) tahun 2010 menyebutkan setiap 25 detik terdapat 1 kasus SKA baru dan setiap 60 detik setidaknya 1 kematian terkait SKA (LloydJones et al., 2010). Lebih dari 1,1 juta penderita terdiagnosa SKA tahun 2010 di Amerika (Go et al., 2013).

Pemberian terapi reperfusi tepat waktu sangat penting untuk meningkatkan kelangsungan hidup. Keterlambatan pemberian terapi reperfusi pada penderita dapat diklasifikasikan sebagai keterlambatan pra RS (RS) (onset-to-door) dan keterlambatan intra RS (door to balloon) (Peng et al., 2014). Keterlambatan dalam reperfusi dapat timbul antara onset gejala dan kontak medis pertama (terkait penderita) dan antara kontak medis pertama dan pengobatan reperfusi (terkait sistem kesehatan) (Bagai et al, 2014c). Keterlambatan pra RS dalam konteks ini adalah interval waktu antara serangan gejala (onset) dan kehadiran di pusat pelayanan IGD (Peng et al., 2014).

Reperfusi koroner yang tepat waktu misalnya, angioplasti, terapi trombolitik; dan pengontrolan terhadap aritmia dapat mengurangi morbiditas dan mortalitas pada orang dengan infark miokard. Mengurangi waktu dari terjadinya awal gejala dengan kedatangan ke RS terhambat oleh sifat alami keputusan mencari bantuan dari pasien (Stain et al, 2014).

Studi menunjukkan waktu keterlambatan pra RS terdapat di semua belahan dunia dengan berbagai variasi waktu keterlambatan. Waktu keterlambatan pra RS atau onset-to-door adalah 2,2 jam di US (McKinley et al., 2009). Studi di Irlandia waktu keterlambatan adalah 4,06 jam untuk SKA, (McKee et al., 2013), di negara China 130 menit (Peng et al., 2014) dan Jordania 7,8 jam dengan kedatangan $>6$ jam sejumlah 114 orang (71,2\%) (Darawad et al., 2015).

Waktu yang dilewatkan dari perkembangan sumbatan akut di pembuluh darah koroner menuju reperfusi meningkatkan resiko kematian pada penderita SKA. Studi di Korea menunjukkan bahwa penderita SKA dengan rata-rata waktu keterlambatan 4 jam memiliki insiden kematian $17,2 \%$ dibandingkan penderita yang datang 1,5 jam setelah timbul gejala yaitu sebanyak $8 \%(\mathrm{Na}$ et al., 2014).

Sebagian besar keterlambatan dalam area pra RS secara keseluruhan adalah karena 
penderita menunggu terlalu lama sebelum menghubungi penyedia layanan kesehatan. Hampir setengah dari semua penderita SKA menunggu lebih dari 4 jam sebelum mencari saran medis (Doggen et al., 2016).

Para peneliti telah mengidentifikasi sejumlah alasan pasien menunda dalam mencari perawatan medis untuk infark miokard. Pasien mengharapkan jenis serangan jantung yang sering mereka lihat di film dan televisi medis: seperti nyeri dada yang mencengkeram dan menyebabkan jatuh ke lantai. Kenyataannya adalah banyak serangan jantung jauh lebih "tenang (silence)," menyebabkan nyeri dada yang ringan atau ketidaknyamanan atau gejala lain seperti sesak napas dan diaphoresis.

Mampu menjangkau penderita pada tahap awal penyakit jantung dapat meningkatkan prospek klinis jangka panjang. Berdasarkan latar belakang di atas, Peneliti tertarik untuk melihat ketidaknyamanan dada yang dialami penderita yang berhubungan dengan keterlambatan waktu terapi reperfusi Sindrom Koroner Akut.

\section{METODE}

Metode yang digunakan adalah observasional analitik dengan pendekatan cross sectional terhadap penderita SKA yang menjalani rawat inap di ruang Intermediate Ward Instalasi PJT RSUP dr. Saiful Anwar Malang pada tanggal 14 September-31 Oktober 2016. Pengambilan sampel menggunakan nonprobability sampling dengan teknik kuota waktu didapatkan sampel sebanyak 60 responden yang memenuhi kriteria inklusi dan eksklusi.
Variabel terikat dalam penelitian ini adalah Interval waktu antara munculnya gejala SKA sampai tiba di pintu IGD (onsetto door), dengan variabel bebas: presentasi gejala. Penelitian ini dilakukan setelah lulus uji etik oleh Komite Etik di Diklit RSUP dr. Saiful Anwar Malang, dan mendapat ijin penelitian dari Direktur RSUP dr. Saiful Anwar Malang. Instrumen yang digunakan dalam penelitian ini adalah (1). Lembar pengumpulan data karakteristik responden, (2). Lembar kuisioner penelitian. Jenis uji bivariat yang digunakan adalah uji Chi-square dengan uji Fisher sebagai alternatifnya. Analisis multivariat menggunakan Regresi Logistik.

\section{HASIL}

Tabel 1. Hasil Analisis Univariat Penderita yang Datang Terlambat (>120 menit) Penelitian di IW Instalasi PJT RSUP dr. Saiful Anwar Malang
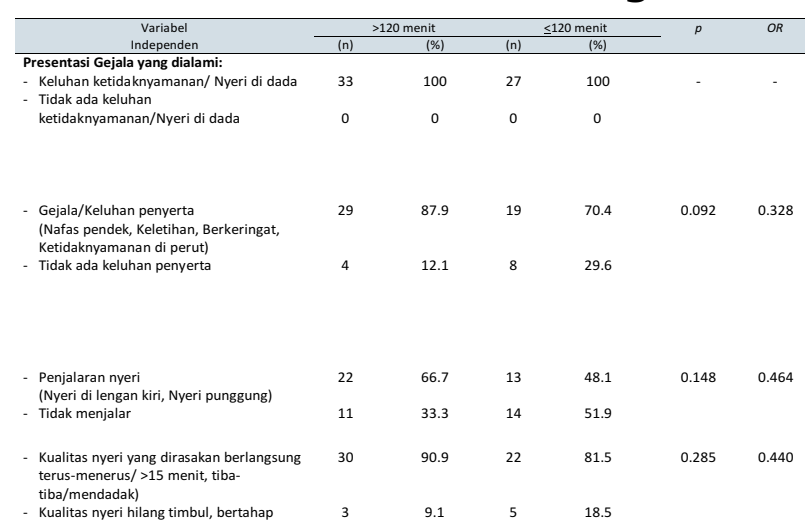

Berdasarkan tabel 1 di atas, pasien SKA yang mengalami keterlambatan (>120 menit) ke rumah sakit mampu reperfusi berusia $>55$ tahun sebanyak 22 orang (66.7\%) dengan rerata 58.52 + SD 8.44; Jarak lokasi onsetto door $<40 \mathrm{~km}$ sebanyak 28 orang $(84.8 \%)$.

Berdasarkan tabel 2, pasien SKA yang mengalami keterlambatan (>120 menit) ke rumah sakit mampu reperfusi berjenis 
kelamin laki-laki sebanyak 22 orang (66.7\%); Persepsi terhadap gejala sebagai penyakit jantung sebanyak 19 orang (57.6\%); Diagnosa medis NSTEMI\&UAP sebanyak 17 orang (51.5\%); Reperfusi tidak dilakukan pada 20 orang $(60.6 \%)$.

Tabel 2. Hasil Analisis Univariat Penderita yang Datang Terlambat ( $>120$ menit) Penelitian di IW Instalasi PJT

\begin{tabular}{lcc}
\hline & \multicolumn{2}{c}{ Jumlah } \\
& $(\mathrm{n})$ & $(\%)$ \\
Jenis Kelamin & & \\
- Laki-laki & 22 & 66.7 \\
- Perempuan & 11 & 33.3 \\
Persepsi terhadap gejala & & \\
- Jantung & 19 & 57.6 \\
- Bukan penyakit jantung & 14 & 42.4 \\
Diagnosa Medis & & \\
- STEMI & 16 & 48.5 \\
- NSTEMI/UAP & 17 & 51.5 \\
Reperfusi & & \\
- PCI & 4 & 12.12 \\
- Trombolitik & 9 & 27.27 \\
- Tidak & 20 & 60.6 \\
\hline
\end{tabular}

Tabel 3. Hasil Analisis Univariat Penderita yang Datang Terlambat (>120 menit) Penelitian di IW Instalasi PJT

\begin{tabular}{|c|c|c|}
\hline & \multicolumn{2}{|c|}{ Jumlah } \\
\hline & (n) & $(\%)$ \\
\hline \multicolumn{3}{|l|}{ Faktor resiko } \\
\hline$-<3$ & 26 & 78.8 \\
\hline$->3$ & 7 & 21.2 \\
\hline - Hipertensi & 12 & 36.4 \\
\hline - DM & 13 & 39.4 \\
\hline - Jantung & 14 & 42.4 \\
\hline Angina & 10 & 30.30 \\
\hline IM & 5 & 15.15 \\
\hline PCI/Stent & 4 & 12.12 \\
\hline - Stroke & 3 & 9.1 \\
\hline - Merokok & 16 & 48.5 \\
\hline
\end{tabular}

Berdasarkan tabel 3 di atas, pasien SKA yang mengalami keterlambatan (>120 menit) ke rumah sakit mampu reperfusi memiliki Faktor resiko $<3$ sebanyak 26 orang (78.8\%), dengan prosentase tertinggi ke rendah: Riwayat Merokok 16 orang (48.5\%); riwayat penyakit/keluhan di Jantung 14 orang (42.4\%) meliputi: angina 10 orang (30.30\%), IMA 5 orang (15.15\%), riwayat pemasangan STENT atau PCI 4 orang (12.12\%); Hipertensi 12 orang (36.4\%) \& DM 13 orang (39.4\%); Stroke sebanyak 3 orang (9.1\%).

\section{Tabel 4. Hasil Analisis Univariat} Penderita yang Datang Terlambat (>120 menit) Penelitian di IW Instalasi PJT RSUP dr. Saiful Anwar Malang

\begin{tabular}{llll}
\hline & \multicolumn{3}{c}{ Jumlah } \\
\cline { 2 - 3 } & Presentasi Gejala yang dialami: & $(\%)$ \\
- Keluhan ketidaknyamanan/ Nyeri di dada & 33 & 100 \\
- Keluhan penyerta & 29 & 7.9 \\
(Nafas pendek, Keletihan, Berkeringat, & & & \\
& Ketidaknyamanan di perut) & & \\
- Penjalaran nyeri & & \\
(Nyeri di lengan kiri, Nyeri punggung) & 22 & 66.7 \\
- Kualitas nyeri yang dirasakan berlangsung terus & 30 & 90.9 \\
$\quad$ menerus/ >15 menit, tibatiba/mendadak) & & \\
\hline
\end{tabular}

Berdasarkan tabel 4 di atas, dapat dilihat pula bahwa seluruh (33 orang) penderita yang datang terlambat (>120 menit) ke rumah sakit, mengeluhkan ketidaknyamanan/nyeri di bagian dada (100\%), disertai keluhan seperti: nafas pendek, keletihan, berkeringat, dan ketidaknyamanan di perut sebanyak 29 orang (87.9\%). Penderita juga mengeluhkan mengalami gejala nyeri di lengan kiri dan atau nyeri punggung sebanyak 22 orang (66.7\%) dimana kualitas nyeri yang dirasakan berlangsung terus-menerus/ $>15$ menit dialami sebanyak 30 orang (90.9\%). 
Tabel 5. Hasil Analisis Bivariat Variabel Independen Presentasi Gejala yang dialami dengan Waktu Onsetto doordi IW Instalasi PJT RSUP dr. Saiful Anwar Malang

\begin{tabular}{|c|c|c|c|c|c|c|}
\hline \multirow{2}{*}{$\begin{array}{c}\text { Variabel } \\
\text { Independen }\end{array}$} & \multicolumn{2}{|c|}{$>120$ menit } & \multicolumn{2}{|c|}{$\leq 120$ menit } & \multirow[t]{2}{*}{$p$} & \multirow[t]{2}{*}{$O R$} \\
\hline & (n) & (\%) & (n) & $(\%)$ & & \\
\hline \multicolumn{7}{|l|}{ Presentasi Gejala yang dialami: } \\
\hline $\begin{array}{l}\text { - Keluhan ketidaknyamanan/ Nyeri di dada } \\
\text { - Tidak ada keluhan }\end{array}$ & 33 & 100 & 27 & 100 & - & - \\
\hline ketidaknyamanan/Nyeri di dada & 0 & 0 & 0 & 0 & & \\
\hline $\begin{array}{l}\text { - Gejala/Keluhan penyerta } \\
\text { (Nafas pendek, Keletihan, Berkeringat, } \\
\text { Ketidaknyamanan di perut) }\end{array}$ & 29 & 87.9 & 19 & 70.4 & 0.092 & 0.328 \\
\hline - Tidak ada keluhan penyerta & 4 & 12.1 & 8 & 29.6 & & \\
\hline $\begin{array}{l}\text { - Penjalaran nyeri } \\
\text { (Nyeri di lengan kiri, Nyeri punggung) }\end{array}$ & 22 & 66.7 & 13 & 48.1 & 0.148 & 0.464 \\
\hline - Tidak menjalar & 11 & 33.3 & 14 & 51.9 & & \\
\hline $\begin{array}{l}\text { - Kualitas nyeri yang dirasakan berlangsung } \\
\text { terus-menerus/ }>15 \text { menit, tiba- } \\
\text { tiba/mendadak) }\end{array}$ & 30 & 90.9 & 22 & 81.5 & 0.285 & 0.440 \\
\hline - Kualitas nyeri hilang timbul, bertahap & 3 & 9.1 & 5 & 18.5 & & \\
\hline
\end{tabular}

\begin{tabular}{lllll}
\hline Total & 33 & 58.33 & 27 & 41.67
\end{tabular}

Uji Chi-square, *Uji Fisher

Berdasarkan tabel 5 di atas pula diketahui bahwa presentasi gejala terhadap interval waktu onsetto door memiliki nilai signifikansi ( $p$ >0.05) sehingga dapat disimpulkan tidak memiliki hubungan signifikan secara statistik (HO gagal ditolak).

Tabel 6. Hasil Uji Multivariat Variabel Independen dengan Onsetto door pada Pemodelan Akhir Multivariat

\begin{tabular}{lccc}
\hline \multicolumn{1}{c}{ Variabel } & B & Pvalue & OR (95\% CI) \\
Gejala penyerta & 1.525 & 0.048 & $\begin{array}{c}4.596(1.014- \\
20.828)\end{array}$ \\
$\begin{array}{l}\text { Mengenali tanda } \\
\text { gejala }\end{array}$ & 20.885 & 0.999 & 1175047434 \\
$\begin{array}{l}\text { Perilaku/Respon awal } \\
\text { saat onset }\end{array}$ & 1.447 & 0.020 & $4.252(1.259$ \\
Constant & & & $14.363)$ \\
\hline
\end{tabular}

Uji regresi logistik dilakukan dengan metode backward LR. Berdasarkan hasil uji disimpulkan bahwa variabel bebas dalam penelitian ini hanya gejala yang menyertai ketidaknyamanan/nyeri dada penderita saat mengalami gejala (onset) yang memiliki pengaruh terhadap interval waktu onsetto door dengan nilai signifikansi $\mathrm{p}=0.048$ dengan kekuatan hubungan (OR) atau nilai Exp (B) 4.596 dan $\mathrm{p}=0.020$ dengan nilai $\mathrm{OR}=4.252$.

Berdasarkan hasil analisis regresi logistik pada tabel 6, variabel presentasi gejala yang menyertai dan perilaku/respon pertama saat 
muncul gejala berpengaruh positif terhadap interval waktu onsetto door dengan kekuatan hubungan lebih tinggi pada presentasi gejala yang menyertai.

Keputusan uji hipotesis pada analisis multivariat adalah $\mathrm{HO}$ ditolak jika presentasi gejala, situasi, perilaku, pengetahuan, sikap dan keyakinan berperan secara bersamasama sebagai prediktor interval waktu onsetto door di Ruang Intermediate Ward PJT RSUP dr. Saiful Anwar Malang. Hasil uji multivariat pada penelitian ini hanya presentasi gejala yang menyertai dan perilaku/respon pertama saat muncul gejala yang berpengaruh terhadap interval waktu onsetto door di RS, sehingga HO gagal ditolak.

\section{PEMBAHASAN}

Berdasarkan tabel di atas dapat diintepretasikan bahwa semua penderita (100\%) mengeluhkan ketidaknyamanan/nyeri di dada. Ketidaknyamanan yang dirasakan berupa rasa panas, terbakar dan atau nyeri. Setelah dilakukan analisis bivariat menggunakan uji Chi-square dengan uji Fisher exact sebagai alternatifnya didapatkan bahwa nilai p untuk variabel presentasi gejala, meliputi: Keluhan dari gejala yang menyertai ketidaknyamanan/nyeri dada adalah sebesar (0.092); Penjalaran nyeri adalah sebesar (0.148); dan Kualitas nyeri yang dirasakan berlangsung terus-menerus/ $>15$ menit adalah sebesar (0.285). Nilai p>0.05 maka dapat dinyatakan bahwa tidak terdapat hubungan antara presentasi gejala terhadap interval waktu antara munculnya gejala dengan waktu kedatangan penderita di RS. Hasil analisis multivariat menunjukkan ada 1 variabel yang bermakna yaitu presentasi gejala dengan sub variabel gejala yang menyertai berhubungan dengan interval waktu onsetto door $(\mathrm{p}=0.048)$.

Sesuai dengan hasil penelitian (O'Donnell and Moser, 2012) yang melakukan analisis mendalam tentang pengalaman gejala infark miokard pada pasien dan menjelaskan perilaku mencari bantuan mereka sebagai respon terhadap gejala, didapatkan 2 kategori infark miokard yang berbeda yaitu, infark miokard onset cepat dan onset lambat. Infark miokard onset lambat ditandai dengan onset gejala ringan yang bertahap, sedangkan infark miokard onset cepat menggambarkan onset nyeri dada yang tiba-tiba. Partisipan dengan infark miokard onset cepat (36\%) dengan cepat menghubungkan gejala mereka dengan penyebab jantung, yang mempercepat pertolongan pencarian yang tepat.

Onset lambat atau cepat secara patofisiologi dapat dikarenakan sumbatan baik total maupun partial/subtotal meskipun ada juga yang disebabkan obstruksi dinamis akibat spasme lokal dari arteri koronaria epikardial, dimana ke semuanya akan mengarah ke pembatasan aliran darah ke otot jantung. Berkurangnya aliran darah koroner menyebabkan terjadinya iskemia miokardium. Pasokan oksigen yang berhenti selama kurang lebih 20 menit menyebabkan miokardium mengalami nekrosis (SKA) (PERKI, 2015). Hasil analisis Silvain et al. (2011) didapatkan bahwa komposisi trombus dipengaruhi oleh waktu iskemik, dimana terjadi peningkatan $2 x$ lipat kadar fibrin per jam iskemik (adjusted OR: 2.00 [Cl 95: 1.03 to 3.7]; $p=0.01)$. Sebanyak 45 trombus 
partisipan dianalisa menggunakan mikroskop electron. Thrombus tua terdiri dari thrombus kaya fibrin (terbentuk >3 jam) dengan komposisi platelet $<30 \%$ dan fibrin $>70 \%$, sedangkan trombus baru adalah trombus yang kaya platelet yang terbentuk beberapa jam sebelum onset gejala terjadi (platelet $>30 \%$ dan fibrin $<70 \%$ ).

Meskipun dalam penelitian ini pemeriksaan trombus pada penderita tidak dilakukan sehingga tidak diketahui apakah jenis trombus yang dimiliki merupakan thrombus tua atau muda, akan tetapi dapat terlihat dalam hasil penelitian (tabel 1) penderita yang datang terlambat $(>120$ menit) memiliki diagnosa medis NSTEMI/UAP $51.5 \%$, dimana menurut Boden et al. (2008), koyaknya plak besar akan mengakibatkan oklusi total pada arteri koroner sehingga menyebabkan STEMI, dimana ruptur plak yang lebih kecil mengakibatkan oklusi parsial (subtotal) sehingga menyebabkan UA atau NSTEMI. Thrombus besar terdiri dari 2 komponen yaitu korpus merah (red corpus/ red thrombus) yang terbentuk dari fibrin dan sel darah merah atau eritrosit (thrombus kaya fibrin) dan white head/white thrombus yang terbentuk dari agregasi platelet (thrombus kaya platelet). Plak kecil yang ruptur lebih banyak terdiri dari agregasi platelet dengan sedikit fibrin.

Selain itu, sesuai dengan penelitian di Pakistan dimana presentasi gejala tidak berpengaruh terhadap keterlambatan, dimana terjadi keterlambatan waktu pra rumah sakit selama 7 jam pada wanita dan 3.5 jam pada pria $(p=0.001)$. Berdasarkan hasil penelitian kebanyakan pria terlambat datang ke RS karena faktor terkait individu, seperti menunggu gejala mereda $(p=<0,001)$, tidak mengenali gejalanya sebagai jantung $(p<0,001)$, dan respon perilaku terhadap gejala ( $p=0.08)$ (Allana and Delta, 2014).

Berdasarkan hasil penelitian analisis univariat pada mereka yang datang terlambat (>120 menit) di dapatkan $66.7 \%$ pria, $63.6 \%$ melakukan penanganan sendiri, dimana $39.4 \%$ memilih menunggu gejala nyeri/ketidaknyamanannya hilang/mereda sendiri. Persepsi terhadap gejala yang dialami 42.4\% menganggap bukan penyakit jantung. Pengetahuan penderita tentang gejala spesifik jantung didapatkan $42.4 \%$ dan tidak spesifik jantung sejumlah $36.4 \%$. Dapat terlihat bahwa sebagian besar mereka yang datang terlambat (>120 menit) lebih memilih untuk menangani sendiri dan menganggap gejala yang dirasakan bukan karena jantung ditambah pula dengan kurang dari setengah dari mereka yang memiliki pengetahuan tentang gejala baik yang spesifik maupun yang tidak spesifik jantung.

Penelitian yang dilakukan Darawad et al. (2015) menunjukkan hasil bahwa waktu keterlambatan berkorelasi positif dengan persepsi kesehatan $(r=0.469)$. Hal ini dapat terjadi karena kurang serius/parah dari gejala yang dirasakan dan kurangnya kerentanan yang dirasakan sehingga penderita tidak mempersepsikan gejala sebagai tanda penyakit jantung atau tidak mengaitkan gejala dengan jantung.

Hasil penelitian juga menunjukkan mereka yang interval waktu onsetto door $>120$ menit sebanyak $33.33 \%$ berjenis kelamin wanita, sebanyak $39.4 \%$ memiliki DM, sebanyak $66.7 \%$ berusia $>55$ tahun. Menurut Carlton, et al. (2015) kelompok 
khusus seperti wanita, mereka yang dengan DM dan lansia memiliki gejala tidak jelas dan atypical. Atypical pada unstable angina pectoris nyerinya beberapa detik/menit, area nyeri sempit, dipicu secara mekanis (palpasi, rotasi) dan nyeri tergantung dari lokasi. Senada dengan Carlton et al. (2015), Charney (2011) dan McLaughlin (2014) mengatakan bahwa wanita dengan penyakit arteri koroner lebih mungkin untuk mengeluh mual atau ketidaknyamanan perut; leher, tenggorokan, atau nyeri rahang; sesak napas; atau kelemahan atau kelelahan daripada gejala yang lebih klasik dari nyeri dada. Wanita yang tampak sakit akut bahkan jika mereka tidak mengeluh nyeri dada harus dipertimbangkan kemungkinan iskemia koroner.

Gejala yang terus-menerus di alami secara signifikan dikaitkan dengan waktu keterlambatan yang lebih pendek. Gejala onset mendadak dikaitkan dengan keterlambatan yang lebih singkat kecuali pada kelompok UAP/ATS. Gejala yang digambarkan sebagai sakit perut, secara signifikan terkait dengan waktu keterlambatan yang lebih pendek pada kelompok STEMI, sedangkan gejala kelelahan dikaitkan dengan waktu tunda yang lebih lama secara keseluruhan (McKee et al., 2013). Pendapat ini sejalan dengan hasil penelitian dimana penderita yang mengalami keterlambatan datang ke RS sebanyak 51.5\% adalah kelompok NSTEMI/UAP.

Penderita yang mampu mengidentifikasi dengan benar gejala yang dialami/dirasakan adalah prediktor penting untuk mengurangi waktu keterlambatan. Penderita yang mengalami gejala yang berbeda dari yang diharapkan untuk dihubungkan dengan SKA akan memperlambat/menunda penanganan, dan penderita yang mengakui bahwa benar dia mengalami gejala akan memiliki waktu keterlambatan yang pendek. Studi lainnya didapatkan sebanyak $74 \%$ penderita SKA memiliki pengalaman gejala yang tidak sesuai (Song et al., 2010). Gejala khas dari SKA adalah nyeri dada, tetapi beberapa peneliti menemukan bahwa 20\%-33.3\% dari penderita dengan SKA tidak mengalami nyeri/ketidaknyamanan yang terpusat di dada. Beberapa gejala tidak khas, seperti kelemahan, sesak napas, kecemasan, ketidaknyamanan perut atau berkeringat dialami ketika mengalami SKA dan ketidakkhasan gejala tersebut berhubungan dengan keterlambatan pra RS yang substansial. Selain itu beberapa penelitian mengemukakan bahwa seseorang dengan dengan riwayat diabetes dapat mengalami keterlambatan karena buruknya sensitifitas sensorik akibat neuropati yang dimiliki.

Peningkatan intensitas gejala yang dirasakan dan seberapa cepat memiliki gejala onset (gejala berkembang dengan cepat) dikaitkan dengan keterlambatan pra RS yang lebih pendek. Mereka yang mengalami gejala secara terus-menerus (>15 menit) mengalami keterlambatan pra RS pendek sedangkan mereka yang mengalami gejala yang hilang timbul memiliki waktu keterlambatan yang lebih lama lagi.

\section{SIMPULAN}

Terdapat hubungan antara presentasi gejala yang menyertai dengan keterlambatan pra RS pada penderita Sindrom Koroner Akut (SKA) di ruang Intermediate Ward Instalasi PJT RSUP dr. Saiful Anwar Malang. 


\section{DAFTAR PUSTAKA}

Allana, Saleema Mansoor and Delta, Rho. (2014). Factors Associated With Prehospital Delay in Acute Coronary Syndrome, Among Men and Women in Karachi, Pakistan. International Nursing Research Congress, 2014 Theme: Engaging Colleagues: Improving Global Health Outcomes. Held at the Hong Kong Convention and Exhibition Centre, Wanchai, Hong Kong. Sigma Theta Tau International, the Honor Society of nursing http://hdl.handle.net/10755/335593

Bagai A, Jollis JG, Dauerman HL, Peng SA, Rokos IC, Bates ER, French WJ, Granger $C B$, Roe MT. Emergency department bypass for ST-Segment-elevation myocardial infarction patients identified with a prehospital electrocardiogram: a report from the American Heart Association Mission: Lifeline program. Circulation. 2013 Jul 23;128(4):352-9. doi: 10.1161/CIRCULATION AHA.113.002339. Epub 2013 Jun 20. PubMed PMID: 23788525.

Bagai A, Jollis JG, Dauerman HL, Peng SA, Rokos IC, Bates ER, French WJ, Granger $C B$, Roe MT. Emergency department bypass for STSegment-elevation myocardial infarction patients identified with a prehospital electrocardiogram: a report from the American Heart Association Mission: Lifeline program. Circulation. 2013;128:352-359.

Bagai A, Al-Khalidi HR, Muñoz D, Monk L, Roettig ML, Corbett CC, Garvey JL, Wilson $\mathrm{BH}$, Granger $\mathrm{CB}$, Jollis JG. Bypassing the emergency department and time to reperfusion in patients with prehospital
STsegment-elevation: findings from the reperfusion in acute myocardial infarction in Carolina Emergency Departments project. Circ Cardiovasc Interv. 2013; 6: 399-406.

Carlton, Edward W. MBChB; Than, Martin MBBS; Cullen, Louise MBBS; Khattab, Ahmed PhD; Greaves, Kim MD. (2015). 'Chest Pain Typicality' in Suspected Acute Coronary Syndromes and the Impact of Clinical Experience. The American Journal of Medicine, Vol 128, No 10, October 2015. Published by Elsevier Inc. http:// dx.doi.org/10.1016/j.amjmed.2015.04.012

Darawad, M.W., Alfasfos, N., Saleh, Z., Saleh, A.M., Hamdan-Mansour, A., 2015. Predictors of delay in seeking treatment by Jordanian patients with acute coronary syndrome. Int. Emerg. Nurs. doi:10.1016/ j.ienj.2015.09.003

Go, A.S., Mozaffarian, D., Roger, V.L., Benjamin, E.J., Berry, J.D., Borden, W.B., Bravata, D.M., Dai, S., Ford, E.S., Fox, C.S., Franco, S., Fullerton, H.J., Gillespie, C., Hailpern, S.M., Heit, J.A., Howard, V.J., Huffman, M.D., Kissela, B.M., Kittner, S.J., Lackland, D.T., Lichtman, J.H., Lisabeth, L.D., Magid, D., Marcus, G.M., Marelli, A., Matchar, D.B., McGuire, D.K., Mohler, E.R., Moy, C.S., Mussolino, M.E., Nichol, G., Paynter, N.P., Schreiner, P.J., Sorlie, P.D., Stein, J., Turan, T.N., Virani, S.S., Wong, N.D., Woo, D., Turner, M.B., on behalf of the American Heart Association Statistics Committee and Stroke Statistics Subcommittee, 2013. Heart Disease and Stroke Statistics-2013 Update: A Report From the American Heart Association. Circulation 127, e6e245. doi:10.1161/CIR.0b013e31828124ad 
Kesehatan, D., RI, K.K., 2013. Riset Kesehatan Dasar. Jkt. Badan Penelit. Dan Pengemb. Kesehat. Dep. Kesehat. Repub. Indones. Lloyd-Jones, D., Brown, T.M., Carnethon, M., Dai, S., De Simone, G., Ferguson, T.B., Ford, E., Furie, K., Gillespie, C., Go, A., Greenlund, K., Haase, N., Hailpern, S., Ho, P.M., Howard, V., Kissela, B., Kittner, S., Lackland, D., Lisabeth, L., Marelli, A., McDermott, M.M., Meigs, J., Mozaffarian, D., Mussolino, M., Nichol, G., Roger, V.L., Rosamond, W., Sacco, R., Sorlie, P., Stafford, R., Thom, T., Wasserthiel-Smoller, S., Wong, N.D., Wylie-Rosett, J., on behalf of the American Heart Association Statistics Committee and Stroke Statistics Sub committee, 2010. Executive Summary: Heart Disease and Stroke Statistics-2010 Update: A Report From the American Heart Association. Circulation 121, 948-954. doi:10.1161/CIRCULATIONAHA.109.192666

McKee, G., Mooney, M., O’Donnell, S., O'Brien, F., Biddle, M.J., Moser, D.K., 2013. Multivariate analysis of predictors of pre-hospital delay in acute coronary syndrome. Int. J. Cardiol. 168, 2706-2713. doi:10.1016/j.ijcard.2013.03.022

McKinley, S., Dracup, K., Moser, D.K., Riegel, B., Doering, L.V., Meischke, H., et al., 2009. The effect of a short one-on-one nursing intervention on knowledge, attitudes and beliefs related to response to acute coronary syndrome in people with coronary heart disease: a randomized controlled trial. International Journal of Nursing Studies. 46 (8), 1037-1046.

McLaughlin MA. (2014). Cardiovascular care made incredibly easy (3rd ed.). Philadelphia: Wolters Kluwer.
Moser, D.K., Kimble, L.P., Alberts, M.J., Alonzo, A., Croft, J.B., Dracup, K., et al., 2006. Reducing delay in seeking treatment by patients with acute coronary syndrome and stroke a scientific statement from the American heart association council on cardiovascular nursing and stroke council. Circulation. 114 (2), 168-182.

Mozaffarian D, Benjamin EJ, Go AS, Arnett DK, Blaha MJ, Cushman M, de Ferranti S, Després J-P, Fullerton HJ, Howard VJ, Huffman MD, Judd SE, Kissela BM, Lackland DT, Lichtman JH, Lisabeth LD, Liu S, Mackey RH, Matchar DB, McGuire DK, Mohler ER 3rd, Moy CS, Muntner P, Mussolino ME, Nasir K, Neumar RW, Nichol G, Palaniappan L, Pandey DK, Reeves MJ, Rodriguez CJ, Sorlie PD, Stein J, Towfighi A, Turan TN, Virani SS, Willey JZ, Woo D, Yeh RW, Turner MB; on behalf of the American Heart Association Statistics Committee and Stroke Statistics Subcommittee. Heart disease and stroke statistics-2015 update: a report from the American Heart Association. Circulation. 2015; 131:e29-e322.

O’Donnell, S., McKee, G., O'Brien, F., Mooney, M., Moser, D.K., 2012. Gendered symptom presentation in acute coronary syndrome: A cross sectional analysis. Int. J. Nurs. Stud. 49, 1325-1332. doi:10.1016/ j.jinurstu.2012.06.002

Peng, Y.G., Feng, J.J., Guo, L.F., Li, N., Liu, W.H., Li, G.J., Hao, G., Zu, X.L., 2014. Factors associated with prehospital delay in patients with ST-segment elevation acute myocardial infarction in China. Am. J. Emerg. Med. 32, 349-355. doi:10.1016/j.ajem.2013.12.053 
Rivero, F., Bastante, T., Cuesta, J., Benedicto, A., Salamanca, J., Restrepo, J.-A., Aguilar, R., Gordo, F., Batlle, M., Alfonso, F., 2015. Factores asociados al retraso en la demanda de atención médica en pacientes con síndrome coronario agudo con elevación del segmento ST. Rev. Esp. Cardiol.Lang Press Inc.

Vahedian Azimi, A., Alhani, F., Ahmadi, F., Kazemnejad, A., 2010. Effect of familycentered empowerment model on the life style of myocardial infarction patients. Iran J Crit Care Nurs 2, 1-2. 